\title{
Low Erythropoietin Plasma Levels during Exacerbations of COPD
}

\author{
Ernest Sala ${ }^{a, c, d}$ Catalina Balaguer ${ }^{a, d}$ Cristina Villena ${ }^{d}$ Angel Ríos $^{c}$ \\ Aina Noguera ${ }^{b-d}$ Belén Núñez ${ }^{a, c, d} \quad$ Alvar Agustíc-e $^{-e}$ \\ a Servei de Pneumologia and ' Servei d'Anàlisi Clíniques, Hospital Universitari Son Dureta, \\ 'Fundació Caubet-CIMERA, and ${ }^{\mathrm{d}} \mathrm{CIBER}$ de Enfermedades Respiratorias, Mallorca, and ${ }^{\mathrm{e}}$ Thorax Institute, \\ Hospital Clínic, Universitat de Barcelona, Barcelona, Spain
}

\section{Key Words}

Emphysema $\cdot$ Chronic bronchitis $\cdot$ Hemoglobin

\begin{abstract}
Background: It is known that pro-inflammatory cytokines suppress in vitro the gene expression and protein production of erythropoietin (Epo). We hypothesized that systemic inflammation in patients with chronic obstructive pulmonary disease (COPD) may influence Epo production, particularly during episodes of exacerbation of the disease (ECOPD) where an inflammatory burst is known to occur. Objectives: We compared the plasma levels of Epo and high-sensitivity (hs) C-reactive protein (hsC-RP) in patients hospitalized because of ECOPD ( $n=26 ; F^{2} V_{1}: 48 \pm 15 \%$ predicted), patients with clinically stable COPD $\left(n=31 ; \mathrm{FEV}_{1}: 49 \pm 17 \%\right.$ predicted), smokers with normal lung function $(n=9)$, and healthy never smokers $(n=9)$. Methods: Venous blood samples were taken between 9 and 10 a.m. after an overnight fast into tubes with EDTA $(10 \mathrm{ml})$ or without EDTA $(10 \mathrm{ml})$. Plasma levels of Epo (R\&D Systems Inc., Minneapolis, Minn., USA) and hsC-RP (BioSource, Belgium) were determined by ELISA. Results: Log-Epo plasma levels were significantly lower $(0.46$ $\pm 0.32 \mathrm{mU} / \mathrm{ml})$ in ECOPD than in stable COPD $(1.05 \pm 0.23$ $\mathrm{mU} / \mathrm{ml})$, smokers $(0.95 \pm 0.11 \mathrm{mU} / \mathrm{ml})$ and never smokers with normal lung function $(0.92 \pm 0.19 \mathrm{mU} / \mathrm{ml})(p<0.01$,
\end{abstract}

each). In a subset of 8 COPD patients who could be studied both during ECOPD and clinical stability, log-Epo increased from $0.49 \pm 0.42 \mathrm{mU} / \mathrm{ml}$ during ECOPD to $0.97 \pm 0.19 \mathrm{mU} / \mathrm{ml}$ during stability $(p<0.01)$. In patients with COPD log-Epo was significantly related to hsC-RP $(r=-0.55, p<0.0001)$ and circulating neutrophils $(r=-0.48, p<0.0001)$. Conclusions: These results show that the plasma levels of Epo are reduced during ECOPD likely in relation to a burst of systemic inflammation.

Copyright $\odot 2009$ S. Karger AG, Basel

\section{Introduction}

The best known function of erythropoietin (Epo) is the regulation of red blood cell production in the bone marrow [1]. However, Epo has other relevant, albeit less well characterized, biological effects. For instance, expression of the Epo receptor and biologic responses to Epo have been described in endothelial, neural, muscle, and cardiac cells [2-5]. Likewise, Epo appears to mobilize endothelial progenitor cells from the bone marrow (EPCs)

Supported in part by Fondo de Investigaciones Sanitarias 04/1946, Beca del Govern Balear CEA07/001 and ABEMAR.

\section{KARGER}

Fax +4161306 1234 E-Mail karger@karger.ch www.karger.com (c) 2009 S. Karger AG, Basel 0025-7931/10/0803-0190\$26.00/0

Accessible online at:

www.karger.com/res
Dr. Ernest Sala

Servei de Pneumologia, Hospital Universitari Son Dureta

C/Andrea Doria 55

ES-07014 Palma de Mallorca (Spain)

Tel. +34971 175 112, Fax +34971 175 228, E-Mail ernest.sala@ ssib.es 
and to increase neovascularization in coronary ischemia [6]. In fact, in an in vitro angiogenesis assay the stimulation of capillary outgrowth by Epo was comparable to that produced by the vascular endothelial growth factor (VEGF) $[7,8]$. On the other hand, it is known that the pro-inflammatory cytokines interleukin-1 (IL-1) and tumor necrosis factor- $\alpha$ (TNF- $\alpha$ ) suppress Epo gene expression and Epo protein secretion in vitro, and may be responsible for impaired Epo synthesis in inflammatory diseases in vivo [9].

Chronic obstructive pulmonary disease (COPD) is characterized by pulmonary and systemic inflammation $[10,11-14]$, both of which flare up during exacerbations of the disease (ECOPD) [15-19]. Epo regulation in relation to systemic inflammation has been seldom studied in COPD. One study reported that Epo levels were increased in patients with stable COPD with respect to controls, only if anemia (defined by a hemoglobin $(\mathrm{Hb})$ concentration lower than $13.5 \mathrm{~g} / \mathrm{dl}$ ) was present [20]. Interestingly, the subgroup of patients with COPD and anemia showed more systemic inflammation than those without it [18]. To our knowledge, no previous data has been reported on Epo regulation during ECOPD, where a burst of systemic inflammation is known to occur [15-19]. We hypothesized that, contrary to what has been described in patients with stable COPD [20], plasma Epo levels will be reduced during ECOPD. To test this hypothesis, we compared the plasma levels of Epo in patients hospitalized because of ECOPD, patients with stable COPD, smokers or ex-smokers with normal lung function and healthy never smokers. To investigate the role of systemic inflammation, we quantified in these individuals the plasma levels of high-sensitivity (hs) C-reactive protein (hsC-RP).

\section{Methods}

\section{Subjects and Ethics}

We prospectively included in the study 26 patients with ECOPD, 31 patients with clinically stable COPD, 9 smokers or exsmokers with normal lung function and 9 healthy never smokers, all of them male. All participants signed their informed consent once aware of the nature and purpose of the study. The study protocol had been approved by IRB of the Balearic Islands.

\section{Study Design}

Patients with ECOPD $(n=26)$ were consecutively recruited from the emergency room of our hospital. The diagnosis of COPD was established according to the criteria of the Global Initiative for Chronic Obstructive Lung Disease (GOLD) [21]. Exclusion criteria included clinical evidence of pneumonia, pulmonary embolism, acute cardiovascular diseases, renal insufficiency, liver diseases, autoimmune diseases, cancer of any origin, respiratory or metabolic acidosis and signs of gastrointestinal bleeding. According to clinical interview, the onset of ECOPD occurred at least $48 \mathrm{~h}$ prior to hospitalization in all patients studied. In these patients, all tests were performed during the first $24 \mathrm{~h}$ of hospital admission and only if the patient had received a maximum of one dose of systemic corticosteroids and/or antibiotics. In 8 of these 26 ECOPD patients, measurements could be repeated during clinical stability, three months after hospital discharge. Treatment of ECOPD was standardized in all patients and included: (1) aerosolized bronchodilators (ipratropium bromide $500 \mu \mathrm{g}$ and fenoterol $250 \mu \mathrm{g}$ four times daily); (2) systemic glucocorticoids (inpatient regimen: methylprednisolone $40 \mathrm{mg}$ three times daily for one day, $40 \mathrm{mg}$ twice daily one day and $40 \mathrm{mg}$ once daily up to hospital discharge. Home regimen: descending doses of oral prednisone for twelve days starting from $30 \mathrm{mg}$ ); (3) antibiotics (amoxycillin $875 \mathrm{mg}$ and clavulanic acid $175 \mathrm{mg}$ three times daily for seven days or levofloxacin $500 \mathrm{mg}$ once daily for seven days), and (4) controlled oxygen therapy to maintain a transcutaneous oxygen saturation $\left(\mathrm{SaO}_{2}\right)$ above $90 \%$.

Patients with stable COPD $(n=31)$ were consecutively recruited from the outpatient clinic of our institution. The diagnosis of COPD was established according to the GOLD guidelines [21]. Clinical stability was defined by the absence of ECOPD or treatment change during the 8 weeks that precede the inclusion in the study; none of these patients was receiving systemic steroids or domiciliary oxygen therapy at the time of the study and none had neuromuscular, rheumatologic and/or unstable cardiovascular or cerebrovascular disease.

Smokers with normal lung function $(n=9)$ were recruited from the pulmonary function laboratory of our department, whereas healthy volunteers $(n=9)$ were recruited from the general population using a newspaper announcement. All of them were older than 50 years of age, had a sedentary lifestyle, a normal spirometry and wish to participate in the study.

\section{Blood Sampling and Measurements}

Venous blood samples were taken between 9 and 10 a.m. after an overnight fast into tubes with EDTA $(10 \mathrm{ml})$ or without EDTA $(10 \mathrm{ml})$ for biochemical determinations. The latter were centrifuged immediately. After centrifugation serum and plasma were separated in aliquots and stored at $-80^{\circ} \mathrm{C}$ until analysis. Measurements were done in duplicate, and mean values were used for analysis. Total, differential leukocytes and red blood cells counts and $\mathrm{Hb}$ concentration were determined automatically in whole blood (Sysmex K-4500, Toa Medical Electronics Co. Ltd., Kobe, Japan). The plasma levels of Epo (R\&D Systems Inc., Minneapolis, Minn., USA) [22, 23] and hsC-RP (BioSource, Belgium) were determined by ELISA.

\section{Lung Function}

Spirometry (Medical Graphics Corporation, St. Paul, Minn., USA) was determined in all participants according to international guidelines [24, 25]. Reference values were those of a Mediterranean population [25]. In patients hospitalized because of ECOPD, spirometry was determined at hospital discharge. Arterial blood gases (IL BG3, Izasa, Spain) were obtained in all ECOPD on admission breathing room air. $\mathrm{SaO}_{2}$ (Criticare System Inc., Waukesha, Wisc., USA) was obtained in ECOPD and stable patients with COPD also breathing room air. 
Table 1. Anthropometric, clinical and functional data of all participants

\begin{tabular}{|c|c|c|c|c|c|}
\hline & ECOPD & $\begin{array}{l}\text { Stable } \\
\text { COPD }\end{array}$ & Smokers & $\begin{array}{l}\text { Never } \\
\text { smokers }\end{array}$ & $\begin{array}{l}\mathrm{p} \text { value } \\
\text { ANOVA }\end{array}$ \\
\hline $\mathrm{n}$ & 26 & 31 & 9 & 9 & \\
\hline Age, years & $67 \pm 8$ & $68 \pm 7$ & $60 \pm 9$ & $61 \pm 4$ & $<0.05$ \\
\hline Body mass index & $26.3 \pm 5.5$ & $26.4 \pm 4.6$ & $26.8 \pm 2.4$ & $25.0 \pm 3.4$ & NS \\
\hline Active smokers, n (\%) & $13(50)$ & $10(32)$ & $5(56)$ & $\varnothing$ & \\
\hline $\mathrm{FEV}_{1} / \mathrm{FVC}_{\text {post-bronchodilation, }} \%$ & $51 \pm 14^{\mathrm{a}}$ & $51 \pm 14^{\mathrm{a}}$ & $77 \pm 6$ & $92 \pm 14$ & $<0.001$ \\
\hline $\mathrm{FEV}_{\text {1post-bronchodilation }} \%$ & $48 \pm 15^{\mathrm{a}}$ & $49 \pm 17^{\mathrm{a}}$ & $105 \pm 8$ & $103 \pm 10$ & $<0.001$ \\
\hline $\mathrm{FVC}_{\text {post-bronchodilation, }} \%$ & $75 \pm 8^{\mathrm{a}}$ & $76 \pm 10^{\mathrm{a}}$ & $118 \pm 6$ & $108 \pm 4$ & $<0.001$ \\
\hline $\begin{array}{l}\mathrm{FEV}_{\text {lpre-bronchodilation, }} \% \\
\text { GOLD stage, } \mathrm{n}(\%)\end{array}$ & $46 \pm 15^{\mathrm{a}}$ & $50 \pm 18^{\mathrm{a}}$ & $108 \pm 6$ & $109 \pm 5$ & $<0.001$ \\
\hline 1 or 2 & $9(35)$ & $15(48)$ & & & \\
\hline 3 or 4 & $17(65)$ & $16(52)$ & & & \\
\hline Cardiovascular risk factors & $16(46)$ & $18(58)$ & $6(60)$ & $\varnothing$ & \\
\hline
\end{tabular}

a Significantly different from non-COPD controls.

Statistical Analysis

Results are expressed as mean \pm SD. A Kolmogorov-Smirnov test was used to assess if variables followed a normal distribution. The distribution of Epo values was significantly different from a normal distribution and fitted better with a log-normal distribution that was used for statistical analyses. One-way analysis of variance (ANOVA) was used to compare differences between groups, followed by post-hoc contrasts (Bonferroni) if appropriate. The statistical significance of differences in the subset of 8 patients studied during ECOPD and clinical stability was investigated by the paired Student's t test, whereas between patients with and without anemia was investigated by the unpaired Student's t test. The Pearson test was used to analyze potential correlations between variables of interest. Statistical significance was set at $\mathrm{p}<0.05$.

\section{Results}

Table 1 presents the main clinical, anthropometric and lung function data of all participants. Age and body mass index (BMI) were similar in all groups. The prevalence of systemic hypertension, diabetes mellitus and hypercholesterolemia was also similar in COPD patients and smokers with normal lung function, but higher from that seen in healthy subjects. Both groups of COPD patients showed moderate to severe airway obstruction, whereas spirometry was normal in the other two groups (table 1). At the emergency room, patients with ECOPD showed respiratory failure $\left(\mathrm{pH} 7.40 \pm 0.04, \mathrm{PaO}_{2} 59.2 \pm\right.$ $6.4 \mathrm{~mm} \mathrm{Hg}, \mathrm{PaCO}_{2} 43.2 \pm 8.6 \mathrm{~mm} \mathrm{Hg}, \mathrm{SaO}_{2} 90.5 \pm$ $3.7 \%$ ). $\mathrm{SaO}_{2}$ determined at rest in patients with stable
COPD was $94.6 \pm 1.8 \%$. Mean Hb levels were similar in the 4 groups studied (table 2). If anemia is defined by hemoglobin levels lower than $13.0 \mathrm{mg} / \mathrm{dl}$ [22], 4 of the 31 patients with stable COPD (13\%) and 7 of the 26 patients with ECOPD (27\%) had anemia.

Table 2 shows the individual and mean values (bars) of log-Epo plasma levels in the four groups of individuals studied. These were significantly lower $(0.46 \pm 0.32 \mathrm{mU} /$ $\mathrm{ml})$ in patients with ECOPD than in those clinically stable $(1.05 \pm 0.23 \mathrm{mU} / \mathrm{ml})$, smokers with normal lung function $(0.95 \pm 0.11 \mathrm{mU} / \mathrm{ml})$ and never smokers $(0.92$ $\pm 0.19 \mathrm{mU} / \mathrm{ml}$ ) (p $<0.01)$. log-Epo plasma levels in patients with stable COPD were not significantly different from those of smokers with normal lung function and never smokers (table 2). Likewise, they were not different between GOLD stages of disease severity (table 3). In the subset of 8 COPD patients studied under both conditions, log-Epo plasma levels increased ( $\mathrm{p}<0.01$ ) from $0.49 \pm$ $0.42 \mathrm{mU} / \mathrm{ml}$ during ECOPD to $0.97 \pm 0.19 \mathrm{mU} / \mathrm{ml}$ at clinical stability (table 4). Neither the presence of CV risk factors (systemic hypertension, diabetes mellitus and hypercholesterolemia) nor active smoking influence Epo plasma levels during ECOPD or in stable conditions (data not shown).

During ECOPD, there was evidence of a flare-up of systemic inflammation, as shown by the higher leukocyte and neutrophil counts (table 2), as well as higher plasma hsC-RP levels $(\mathrm{p}<0.01)$ in patients with ECOPD $(49.5 \pm 42.6 \mathrm{mg} / \mathrm{l})$ than in those with clinically stable disease $(4.5 \pm 4.7 \mathrm{mg} / \mathrm{l})$, smokers with normal lung 
Table 2. Mean ( \pm SD) values of the blood variables determined in the study

\begin{tabular}{lccccc}
\hline & ECOPD & $\begin{array}{l}\text { Stable } \\
\text { COPD }\end{array}$ & Smokers & $\begin{array}{l}\text { Never } \\
\text { smokers }\end{array}$ & $\begin{array}{l}\text { p value } \\
\text { (ANOVA) }\end{array}$ \\
\hline $\mathrm{n}$ & 26 & 31 & 9 & 9 & \\
Epo, $\mathrm{mU} / \mathrm{ml}$ & $3.7 \pm 2.7^{\mathrm{a}, \mathrm{b}}$ & $12.9 \pm 7.9$ & $9.1 \pm 2.5$ & $9.1 \pm 4.4$ & $<0.01$ \\
$\mathrm{log}-\mathrm{Epo}, \mathrm{mU} / \mathrm{ml}$ & $0.46 \pm 0.32^{\mathrm{a}, \mathrm{b}}$ & $1.05 \pm 0.23$ & $0.95 \pm 0.11$ & $0.92 \pm 0.19$ & $<0.01$ \\
Hemoglobin, g/dl & $14.2 \pm 1.6$ & $14.8 \pm 1.6$ & $15.0 \pm 1.1$ & $14.9 \pm 1.2$ & $\mathrm{NS}$ \\
$\mathrm{h}$ C-RP, $\mathrm{mg} / \mathrm{l}$ & $49.5 \pm 42.6^{\mathrm{a}, \mathrm{b}}$ & $4.5 \pm 4.7$ & $2.9 \pm 2.3$ & $1.3 \pm 1.1$ & $<0.01$ \\
Leukocytes, $\times 10^{3} / \mathrm{ml}$ & $10.8 \pm 2.9^{\mathrm{a}, \mathrm{c}}$ & $7.4 \pm 1.9^{\mathrm{c}}$ & $8.7 \pm 3.0^{\mathrm{c}}$ & $5.3 \pm 1.2$ & $<0.01$ \\
Neutrophils, $\times 10^{3} / \mathrm{ml}$ & $9.3 \pm 2.6^{\mathrm{a}, \mathrm{b}}$ & $4.8 \pm 1.6^{\mathrm{c}}$ & $5.4 \pm 2.5^{\mathrm{c}}$ & $3.1 \pm 1.1$ & $<0.01$ \\
\hline
\end{tabular}

a Significantly different from stable COPD; ${ }^{\mathrm{b}}$ significantly different from non-COPD controls; ${ }^{\mathrm{c}}$ significantly different from never smokers.

Table 3. Erythropoietin plasma levels, hemoglobin and systemic inflammation in ECOPD and stable COPD patients according to GOLD stages

\begin{tabular}{lcccc}
\hline & $\begin{array}{l}\text { ECOPD } \\
\text { GOLD 1-2 }\end{array}$ & $\begin{array}{l}\text { ECOPD } \\
\text { GOLD 3-4 }\end{array}$ & $\begin{array}{l}\text { Stable COPD } \\
\text { GOLD 1-2 }\end{array}$ & $\begin{array}{l}\text { Stable COPD } \\
\text { GOLD 3-4 }\end{array}$ \\
\hline $\mathrm{N}$ & 9 & 17 & 15 & 16 \\
Epo, $\mathrm{mU} / \mathrm{ml}$ & $2.9 \pm 1.6^{\mathrm{a}}$ & $4.0 \pm 3.0^{\mathrm{b}}$ & $11.7 \pm 6.2$ & $14.2 \pm 9.3$ \\
$\mathrm{log}-\mathrm{Epo}, \mathrm{mU} / \mathrm{ml}$ & $0.42 \pm 0.3^{\mathrm{a}}$ & $0.50 \pm 0.31^{\mathrm{b}}$ & $1.02 \pm 0.19$ & $1.07 \pm 0.27$ \\
$\mathrm{Hb}, \mathrm{g} / \mathrm{dl}$ & $15.1 \pm 1.2^{\mathrm{a}}$ & $14.1 \pm 1.8^{\mathrm{b}}$ & $15.0 \pm 1.2$ & $14.6 \pm 1.9$ \\
$\mathrm{hsC}-\mathrm{RP}, \mathrm{mg} / \mathrm{l}$ & $59.3 \pm 41.5^{\mathrm{a}}$ & $50.1 \pm 43.6^{\mathrm{b}}$ & $3.8 \pm 3.5$ & $5.2 \pm 5.6$ \\
Leukocytes, $\times 10^{3} / \mathrm{ml}$ & $10.8 \pm 2.7^{\mathrm{a}}$ & $10.9 \pm 3.3^{\mathrm{b}}$ & $7.5 \pm 1.9$ & $7.3 \pm 1.9$ \\
Neutrophils, $\times 10^{3} / \mathrm{ml}$ & $9.4 \pm 2.6^{\mathrm{a}}$ & $9.5 \pm 2.8^{\mathrm{b}}$ & $4.9 \pm 1.5$ & $4.7 \pm 1.7$ \\
\hline
\end{tabular}

${ }^{\mathrm{a}} \mathrm{p}<0.01$ : significantly different from stable COPD GOLD stage $1-2 ;{ }^{\mathrm{b}} \mathrm{p}<0.01$ : significantly different from stable COPD GOLD stage 3-4.

function $(2.9 \pm 2.3 \mathrm{mg} / \mathrm{l})$ and never smokers $(1.3 \pm 1.1$ $\mathrm{mg} / \mathrm{l})$. The latter was confirmed in the subset of $8 \mathrm{COPD}$ patients studied both during ECOPD $(10.1 \pm 4.1 \mathrm{mg} /$ $\mathrm{ml})$ and at stability $(4.6 \pm 4.0 \mathrm{mg} / \mathrm{ml}, \mathrm{p}<0.01)$ (table 4$)$. In patients with COPD, Epo levels were related to both hsC-RP ( $\mathrm{r}=-0.55, \mathrm{p}<0.0001$; fig. 1a) and circulating neutrophils $(\mathrm{r}=-0.48, \mathrm{p}<0.0001$; fig. $1 \mathrm{~b})$, but not to $\mathrm{Hb}$ levels $(\mathrm{r}=-0.05, \mathrm{p}=0.7)$ or arterial $\mathrm{PO}_{2}(\mathrm{r}=0.04, \mathrm{p}=$ 0.8 ), albeit it should be noted that we measured arterial $\mathrm{PO}_{2}$ only in patients with ECOPD. HsC-RP levels were similar in different GOLD stages of disease severity (table 3).

When patients were divided according to the presence or absence of anemia (hemoglobin levels lower than $13.0 \mathrm{mg} / \mathrm{dl}$ [22]), we did not observe any difference
Table 4. Mean ( $\pm \mathrm{SD})$ values of erythropoietin, systemic inflammation and hemoglobin levels in 8 COPD patients studied during an exacerbation and in stability

\begin{tabular}{lcc}
\hline & ECOPD & COPD in stability \\
\hline Epo, $\mathrm{mU} / \mathrm{ml}$ & $4.6 \pm 4.0^{*}$ & $10.1 \pm 4.1$ \\
$\log -\mathrm{Ep}, \mathrm{mU} / \mathrm{ml}$ & $0.49 \pm 0.42^{*}$ & $0.97 \pm 0.19$ \\
$\mathrm{hsC}-\mathrm{RP}, \mathrm{mg} / \mathrm{l}$ & $66.1 \pm 35.9^{*}$ & $7.6 \pm 8.3$ \\
Leukocytes, $\times 10^{3} / \mathrm{ml}$ & $11.5 \pm 2.4^{*}$ & $8.9 \pm 2.8$ \\
Neutrophils, $\times 10^{3} / \mathrm{ml}$ & $10.2 \pm 2.1^{*}$ & $5.5 \pm 2.6$ \\
$\mathrm{Hb}, \mathrm{g} / \mathrm{dl}$ & $13.5 \pm 1.7$ & $13.8 \pm 0.9$ \\
\hline
\end{tabular}

${ }^{*} \mathrm{p}<0.05$ : significantly different from stable COPD. 

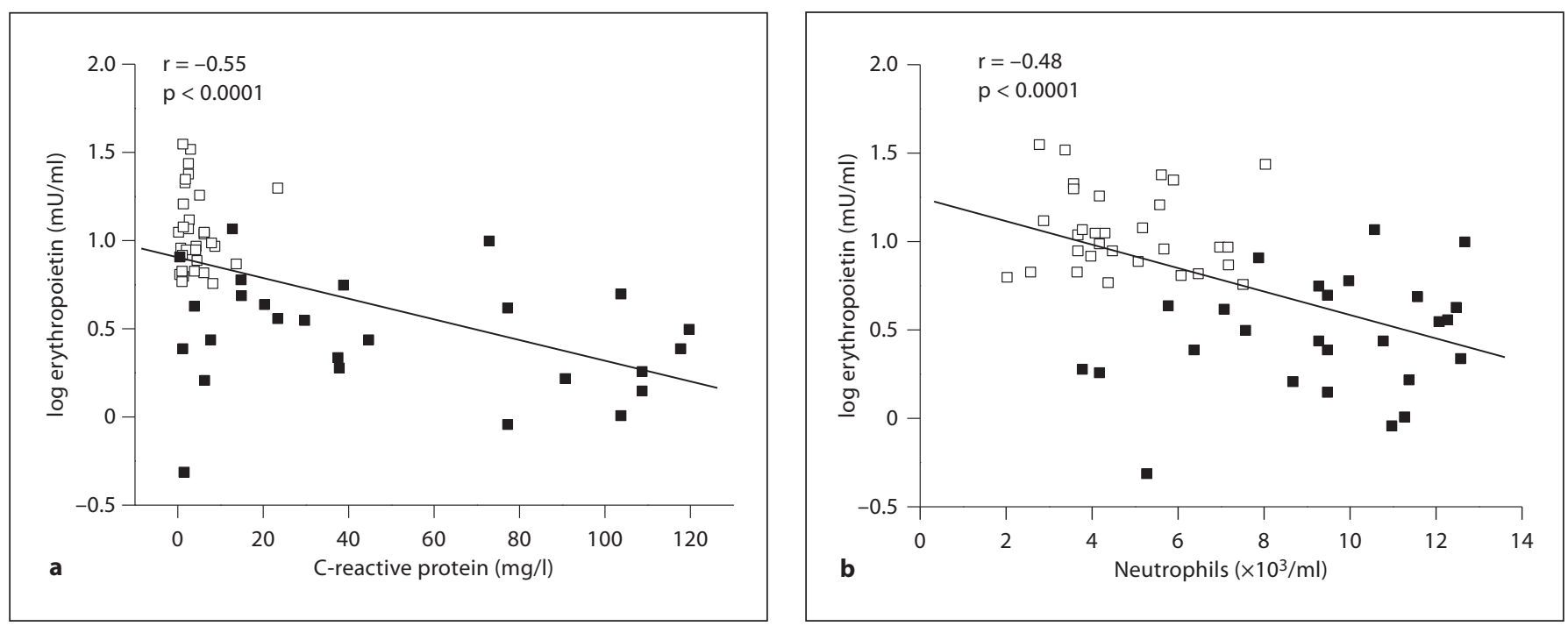

Fig. 1. Significant negative relationship between log-Epo and both hsC-RP plasma levels $(r=-0.55, p<0.0001)$ (a) and neutrophils $(\mathrm{r}=-0.48, \mathrm{p}<0.0001)$ (b). See text for further details. Stable COPD, $\mathrm{n}=31$; ECOPD, $\mathrm{n}=26$.

Table 5. Erythropoietin plasma levels and systemic inflammation in ECOPD and stable COPD patients with and without anemia

\begin{tabular}{lcccc}
\hline & $\begin{array}{l}\text { ECOPD } \\
\text { without anemia }\end{array}$ & $\begin{array}{l}\text { ECOPD } \\
\text { with anemia }\end{array}$ & $\begin{array}{l}\text { Stable COPD } \\
\text { without anemia }\end{array}$ & $\begin{array}{l}\text { Stable COPD } \\
\text { with anemia }\end{array}$ \\
\hline $\mathrm{n}$ & 19 & 7 & 27 & 4 \\
$\mathrm{Hb}, \mathrm{g} / \mathrm{dl}$ & $14.9 \pm 1.2^{\mathrm{a}}$ & $12.4 \pm 0.6$ & $15.1 \pm 1.3^{\mathrm{b}}$ & $12.5 \pm 0.9$ \\
$\mathrm{log}-\mathrm{Epo}, \mathrm{mU} / \mathrm{ml}$ & $0.44 \pm 0.3^{\mathrm{c}}$ & $0.51 \pm 0.53^{\mathrm{d}}$ & $1.02 \pm 0.21$ & $1.26 \pm 0.27$ \\
$\mathrm{hsC}-\mathrm{RP}, \mathrm{mg} / \mathrm{l}$ & $56.8 \pm 43.9^{\mathrm{c}}$ & $29.2 \pm 33.0^{\mathrm{d}}$ & $3.9 \pm 3.2$ & $8.5 \pm 10.2$ \\
Leukocytes, $\times 10^{3} / \mathrm{ml}$ & $10.5 \pm 3.1$ & $11.6 \pm 2.1$ & $7.5 \pm 2.0$ & $6.6 \pm 1.2$ \\
Neutrophils, $\times 10^{3} / \mathrm{ml}$ & $9.1 \pm 2.7^{\mathrm{c}}$ & $10.1 \pm 2.6^{\mathrm{d}}$ & $4.8 \pm 1.6$ & $4.5 \pm 1.2$ \\
\hline
\end{tabular}

${ }^{\mathrm{a}} \mathrm{p}<0.05$ : significantly different from ECOPD with anemia; ${ }^{\mathrm{b}} \mathrm{p}<0.05$ : significantly different from stable COPD with anemia; ${ }^{c} \mathrm{p}<0.05$ : significantly different from stable COPD without anemia; ${ }^{\mathrm{d}} \mathrm{p}<0.05$ : significantly different from stable COPD with anemia.

in log-Epo plasma levels in both stable patients and patients with ECOPD (table 5). Also, hsC-RP plasma levels as well as leukocyte and neutrophil counts were similar in patients with and without anemia, both during ECOPD and clinical stability (table 5). Finally, ECOPD patients, with and without anemia, had lower log-Epo plasma levels and higher systemic inflammation $(\mathrm{p}<$ 0.05 , both) than stable COPD patients, with and without anemia (table 4).

\section{Discussion}

The main and novel finding of this study is that Epo plasma levels are reduced during ECOPD likely in relation to a burst of systemic inflammation.

\section{Previous Studies}

Several previous studies have investigated Epo regulation in patients with stable COPD [20, 27-30]. In general, these studies showed that Epo concentration in COPD 
was similar to that seen in control subjects, except in those patients with chronic respiratory failure, severe nocturnal desaturation or anemia, in whom Epo levels were increased [20,27-29]. The influence of systemic inflammation on Epo regulation in COPD is less well understood. A previous study in patients with stable COPD and mild arterial hypoxemia failed to find any relationship between the systemic inflammation and Epo levels [20]. All in all, these observations are in keeping with the results of our study since we also found that patients with stable COPD with mild hypoxemia had similar Epo plasma levels than controls and that, in the subgroup of patients with anemia Epo levels were increased (table 5), although they do not reach statistical significance probably due to a type II error since only 4 patients with stable COPD had anemia.

\section{Interpretation of Findings}

We found that Epo plasma levels are significantly reduced during ECOPD (tables 1, 4). In keeping with this observation, a previous paper in patients with a number of causes of acute respiratory failure, including COPD, pneumonia and heart failure, also reported reduced Epo plasma levels [31]. We propose here that Epo down-regulation during ECOPD can be explained by the burst of inflammation that occurs during these clinical circumstances [32], as shown here by a significant increase in leukocyte and neutrophil counts, as well as by the raised concentration of hsC-RP during ECOPD (table 5). Several pieces of evidence support this proposal. First, in vitro experiments have demonstrated that IL-1 and TNF- $\alpha$ suppress Epo expression and secretion by activating the transcription factors GATA-2 and NF- $\kappa B$ [9]. Second, clinical investigations indicate that TNF- $\alpha$ suppresses Epo secretion in patients with advanced solid tumors and chronic infection $[33,34]$. Third, Epo plasma levels in anemic patients who suffer concomitantly of other inflammatory process are often lower than expected in relation to their hemoglobin concentration [35]. Fourth and finally, the results of our study also support this proposal by identifying a significant negative association between Epo plasma levels and both hsC-RP and neutrophils in the patients studied here (fig. 1). Interestingly, this inflammatory mechanism appears to overcome the regulation of EPO by oxygen, given that the hypoxemia that occurs during exacerbations of COPD would be a strong stimulus for Epo production $[36,37]$.

The prevalence of anemia in different studies of patients with clinically stable COPD ranges between 13 and
$17 \%[20,38]$. Our results in stable patients $(13 \%)$ are in keeping with these estimates. Interestingly, the percentage of patients with anemia during ECOPD appeared to be much higher (27\%). The fact that ECOPD patients with anemia showed lower log-Epo plasma levels $(0.51 \pm 0.53$ vs. $1.26 \pm 0.27 \mathrm{mU} / \mathrm{ml}, \mathrm{p}<0.05)$ and higher both hsC-RP concentrations $(29.2 \pm 33.0$ vs. $8.5 \pm 10.2 \mathrm{mg} / \mathrm{l}, \mathrm{p}<0.05)$ and neutrophil cell counts $(10.1 \pm 2.6$ vs. $4.5 \pm 1.2 \times$ $\left.10^{3} / \mathrm{ml}, \mathrm{p}<0.05\right)$ than those with stable COPD and anemia (table 5), is in keeping with our interpretation that Epo is downregulated during ECOPD regardless of the existence of anemia and likely in relation to systemic inflammation.

\section{Clinical Implications}

We did not explore the potential clinical implications of the observed Epo downregulation during ECOPD. However, we can speculate that these reduced Epo levels can contribute to: (1) the increased prevalence of anemia reported in COPD [38], because Epo is a key regulator of red blood cell production in the bone marrow [1]; (2) cardiovascular morbidity and mortality during ECOPD [39-40] since Epo has been implicated in the neovascularization process that occurs during acute coronary artery events [6], and, perhaps (3) the pathogenesis of emphysema given that Epo is known to interfere with the VEGF pathway [41], and blockade of VEGF-receptor 2 causes emphysema in experimental animals [42]. Of course, all these possibilities require testing in future studies.

\section{Potential Limitations}

Several potential limitations of our study deserve comment. First, we studied four independent groups of subjects, but results were basically reproduced in the admittedly small subgroup of patients that could be studied both during ECOPD and clinical stability. Second, it has been suggested that the physiological circadian rhythm of Epo is lost in COPD patients [43] and we did not study it, but, as indicated above, all samples were taken at the same time (between 9 and 10 a.m.). Third, we did not measure arterial $\mathrm{PO}_{2}$ in patients with stable COPD and, therefore, we were not able to fully investigate the role of blood oxygenation in these patients. Fourth, we did not study the influence of iron metabolism or red cell life span on Epo levels in our patients. Finally, steroids can certainly reduce inflammation [44] and have the potential to influence Epo gene expression directly in experimental animals [45], but their effects upon Epo regulation in vivo are less clear [46]. In our study, stable COPD 
patients did not receive systemic steroids, and ECOPD patients had received one dose of systemic glucocorticoids before sampling at most.

\section{Conclusions}

Our study shows that Epo plasma levels are reduced during ECOPD and suggest that this is likely related to the burst of systemic inflammation that occurs under these circumstances. The clinical implications of this observation will have to be investigated in future studies.

\section{Acknowledgment}

CIBERES is an initiative of Instituto de Salud Carlos III (Ministerio de Ciencia e Innovación).

\section{References}

1 Jelkmann W: Erythropoietin: structure, control of production, and function. Physiol Rev 1992;72:449-489.

-2 Anagnostou A, Lee ES, Kessimian N, Levinson R, Steiner M: Erythropoietin has a mitogenic and positive chemotactic effect on endothelial cells. Proc Natl Acad Sci USA 1990; 87:5978-5982.

- $3 \mathrm{Wu} \mathrm{H}$, Lee SH, Gao J, Liu X, Iruela-Arispe ML: Inactivation of erythropoietin leads to defects in cardiac morphogenesis. Development 1999;126:3597-3605.

-4 Ogilvie M, Yu X, Nicolas-Metral V, et al: Erythropoietin stimulates proliferation and interferes with differentiation of myoblasts. J Biol Chem 2000;275:39754-39761.

-5 Yasuda Y, Masuda S, Chikuma M, Inoue K, Nagao M, Sasaki R: Estrogen-dependent production of erythropoietin in uterus and its implication in uterine angiogenesis. J Biol Chem 1998;273:25381-25387.

-6 Heeschen C, Aicher A, Lehmann R, et al: Erythropoietin is a potent physiologic stimulus for endothelial progenitor cell mobilization. Blood 2003;102:1340-1346.

7 Pelletier L, Regnard J, Fellmann D, Charbord P: An in vitro model for the study of human bone marrow angiogenesis: role of hematopoietic cytokines. Lab Invest 2000; 80:501-511.

-8 Jaquet K, Krause K, Tawakol-Khodai M, Geidel S, Kuck KH: Erythropoietin and VEGF exhibit equal angiogenic potential. Microvasc Res 2002;64:326-333.

-9 La FK, Reimann C, Jelkmann W, HellwigBurgel T: Inhibition of erythropoietin gene expression signaling involves the transcription factors GATA-2 and NF-kappaB. FASEB J 2002;16:1811-1813.

$\checkmark 10$ Celli BR, MacNee W, Agusti AG, et al: Standards for the diagnosis and treatment of patients with COPD: a summary of the ATS/ ERS position paper. Eur Respir J 2004;23: 932-946.

11 Celli B: ERS/ATS COPD guidelines: novel aspects. Diagnosis and staging. Eur Respir J 2003;24:23A.
12 Agusti AG, Noguera A, Sauleda J, Sala E, Pons J, Busquets X: Systemic effects of chronic obstructive pulmonary disease. Eur Respir J 2003;21:347-360.

13 Wouters EF, Creutzberg EC, Schols AM: Systemic effects in COPD. Chest 2002;121(5 suppl):127S-130S.

14 van Eeden SF, Sin DD: Chronic obstructive pulmonary disease: a chronic systemic inflammatory disease. Respiration 2008; 75 : 224-238.

15 Malo O, Sauleda J, Busquets X, Miralles C, Agusti AG, Noguera A: Inflamación sistémica durante las agudizaciones de la enfermedad pulmonar obstructiva crónica. Arch Bronconeumol 2002;38:172-176.

16 Dentener MA, Creutzberg EC, Schols AM, et al: Systemic anti-inflammatory mediators in COPD: increase in soluble interleukin 1 receptor II during treatment of exacerbations. Thorax 2001;56:721-726.

17 Drost EM, Skwarski KM, Sauleda J, et al: Oxidative stress and airway inflammation in severe exacerbations of COPD. Thorax 2005; 60:293-300.

18 Wedzicha JA, Seemungal TA, MacCallum PK, et al: Acute exacerbations of chronic obstructive pulmonary disease are accompanied by elevations of plasma fibrinogen and serum IL-6 levels. Thromb Haemost 2000; 84:210-215.

19 Zeng M, Wen Y, Liu LY, Wang H, Guan KP, Huang X: Role of TNF- $\alpha$, sTNF-R55 and sTNF-R75 in inflammation of acute exacerbations of chronic obstructive pulmonary disease. Respiration 2009;78:399-403.

20 John M, Hoernig S, Doehner W, Okonko DD, Witt C, Anker SD: Anemia and inflammation in COPD. Chest 2005;127:825-829.

21 Rabe KF, Hurd S, Anzueto A, et al: Global strategy for the diagnosis, management, and prevention of chronic obstructive pulmonary disease: GOLD executive summary. Am J Respir Crit Care Med 2007;176:532555.
22 Lightfoot BO, Mulloy LL, Jagadeesan M, Ahmed S, Balachandran S: ACEi induced attenuation of platelet TIMP-1 production in renal allograft recipients: possible impact on erythropoiesis. Transplant Proc 2002;34: 1806-1807.

-23 Ponce S, Orive G, Hernández RM, Gascón AR, Canals JM, Muñoz MT, Pedraz JL: In vivo evaluation of EPO-secreting cells immobilized in different alginate-PLL microcapsules. J Control Release 2006;116:28-34.

24 World Health Organization: Nutritional anemias: report of a WHO scientific group. Who Tech Report Ser 1968;405.

25 American Thoracic Society Official Statement: Standardization of Spirometry 1994 Update. Am J Respir Crit Care Med 1995; 152:1107-1136.

26 Roca J, Sanchis J, Agustí-Vidal A, et al: Spirometric reference values for a Mediterranean population. Bull Eur Physiopathol Respir 1986;22:217-224.

27 Casale R, Pasqualetti P: Diurnal rhythm of serum erythropoietin circulating levels in chronic obstructive pulmonary disease. Panminerva Med 1997;39:183-185.

28 Fitzpatrick MF, Mackay T, Whyte KF, et al: Nocturnal desaturation and serum erythropoietin: a study in patients with chronic obstructive pulmonary disease and in normal subjects. Clin Sci (Lond) 1993;84:319-324.

29 Tassiopoulos S, Kontos A, Konstantopoulos $\mathrm{K}$, et al: Erythropoietic response to hypoxaemia in diffuse idiopathic pulmonary fibrosis, as opposed to chronic obstructive pulmonary disease. Respir Med 2001;95: 471-475.

30 Guidet B, Offenstadt G, Boffa G, et al: Polycythemia in chronic obstructive pulmonary disease: a study of serum and urine erythropoietin and medullary erythroid progenitors. Chest 1987;92:867-870.

- 31 Pavlisa G, Vrbanic V, Kusec V, Jaksic B: Erythropoietin response after correction of severe hypoxaemia due to acute respiratory failure in chronic obstructive pulmonary disease patients. Clin Sci (Lond) 2004;106: 43-51. 
\$2 Valipour A, Schreder M, Wolzt M, et al: Circulating vascular endothelial growth factor and systemic inflammatory markers in patients with stable and exacerbated chronic obstructive pulmonary disease. Clin Sci (Lond) 2008;115:225-232.

33 Braczkowski R, Romanawsky W, Danikiewicz A, Muc-Wierzgon M, Blazelonis A, Zubelewicz B: Decrease of erythropoietin level by human recombinant tumour necrosis factor alpha (hrec TNFalpha) in patients with advanced cancer. J Biol Regul Homeost Agents 2001;15:366-369.

-34 Ebrahim O, Folb PI, Robson SC, Jacobs P: Blunted erythropoietin response to anaemia in tuberculosis. Eur J Haematol 1995;55:251254.

-35 Jelkmann W: Proinflammatory cytokines lowering erythropoietin production. J Interferon Cytokine Res 1998;18:555-559.
36 Stockmann C, Fandrey J: Hypoxia-induced erythropoietin production: a paradigm for oxygen-regulated gene expression. Clin Exp Pharmacol Physiol 2006;33:968-979.

37 Fandrey J: Oxygen-dependent and tissuespecific regulation of erythropoietin gene expression. Am J Physiol Regul Integr Comp Physiol 2004;286:R977-R988.

38 Cote C, Zilberberg MD, Mody SH, Dordelly LJ, Celli B: Haemoglobin level and its clinical impact in a cohort of patients with COPD. Eur Respir J 2007;29:923-929.

-39 Sin DD, Man SF: Chronic obstructive pulmonary disease as a risk factor for cardiovascular morbidity and mortality. Proc Am Thorac Soc 2005;2:8-11.

40 Sin DD, Anthonisen NR, Soriano JB, Agusti AG: Mortality in COPD: role of comorbidities. Eur Respir J 2006;28:1245-1257.

41 Nakano M, Satoh K, Fukumoto Y, et al: Important role of erythropoietin receptor to promote VEGF expression and angiogenesis in peripheral ischemia in mice. Circ Res 2007;100:662-669.
42 Kasahara Y, Tuder RM, Taraseviciene-Stewart L, et al: Inhibition of VEGF receptors causes lung cell apoptosis and emphysema. J Clin Invest 2000;106:1311-1319.

43 Lim GB, Dodic M, Earnest L, Jeyaseelan K, Wintour EM: Regulation of erythropoietin gene expression in fetal sheep by glucocorticoids. Endocrinology 1996;137:1658-1663.

44 Leng HM, Kidson SH, Keraan MM, Randall GW, Folb PI: Cytokine-mediated inhibition of erythropoietin synthesis by dexamethasone. J Pharm Pharmacol 1996;48:971-974.

45 Amylon MD, Perrine SP, Glader BE: Prednisone stimulation of erythropoiesis in leukemic children during remission. Am J Hematol 1986;23:179-181.

46 Casale R, Pasqualetti P: Diurnal rhythm of serum erythropoietin circulating levels in chronic obstructive pulmonary disease. Panminerva Med 1997;39:183-185. 